\title{
Ultrastructural study of neoplastic cells in Macoma balthica (Bivalvia) from the Gulf of Gdansk (Poland)
}

\author{
Katarzyna Smolarz ${ }^{\mathrm{a},}$, Tristan Renault ${ }^{\mathrm{b}}$ and Maciej Wołowicz ${ }^{\mathrm{a}}$ \\ aLaboratory of Estuarine Ecology, Institute of Oceanography, University of Gdansk, Al. Piłsudskiego \\ 46, 81-378 Gdynia, Poland \\ 'IFREMER, Laboratoire de Génétique et Pathologique, 17390 La Tremblade, France \\ *: Corresponding author : Fax: +48 5862021 65; email : mok@sat.ocean.univ.gda.pl
}

\begin{abstract}
:
In the Baltic clam Macoma balthica from the Gulf of Gdansk, neoplasia is considered as a serious epizootic linked to bad environmental conditions and high levels of pollutants. Previous research was focused on the diagnosis, prevalence, seasonality and histopathological characteristic of the cancer. This study is focused on electron microscopy analyses describing cell ultrastructure abnormalities related to neoplasia. Examinations using the electron microscopy highlighted changes confined to anatomic ultrastructures, shapes and functions of neoplastic cells. The lobulated appearance of the nucleus, changes in cellular matrix and the occurrence of large granular cells with hyperchromatic nuclei, atypical Golgi structures and deterioration of rough endoplasmic reticulum manifested the disease. The presence of atypical mitochondria, free ribosomes and hypertrophic nuclei suggests the adaptation of neoplastic cells to increased mitotic activity, while the observed modification of cellular membranes may reflect functional changes connected to increased pinocytotic activity or intercellular transport. The cancer cells were found to appear in two types, abnormal round-shaped cells and spindle-shaped cells, both with increased frequencies of cell division. Round-shaped cells typical for disseminated neoplasia were observed in all affected bivalves, in a few cases co-occurring with abnormal spherical cells. Spindle-shaped cells containing some intracytoplasmic filaments, and with a tendency of the nuclei to be orientated as in a palisade were interpreted as myofibroblasts-like cells and were observed in five out of eleven clams diagnosed as neoplastic. This finding represents the first demonstration of phenotypic differences in the cell types co-occurring in animals diagnosed as neoplastic and by that suggests coexistence of two types of bivalve cancer, disseminated neoplasia and probable fibrosarcoma.
\end{abstract}

Keywords: Cell ultrastructures; Myofibroblast-like cells; Neoplasia; Macoma balthica; Gulf of Gdansk 


\section{Introduction}

An increase in both the number and types of tumours found worldwide in shellfish has been noted over the past decades. Pathological conditions referring to cancer has been observed in many marine bivalves species (see Mix 1983, Barber 2004, Wołowicz et al. 2005). Proliferative neoplastic disorders in marine invertebrates characterized by a high an euploidy level, nuclear and cellular polymorphism, the presence of numerous nucleoli in the nucleus, and a high mitotic activity were for the first time reported by Farley (1969). The lack of an architectural pattern and epitheliosis has also been noted in cancer diseases (Elston et al. 1992).

Soft tis sue tumours may be classified according to the tis sue they resemble; therefore electron microscopy currently plays a significant role in the evaluation of neoplasias. Farley (1976) and Rasmussen (1986) were the first to describe the basic characteristics of neoplastic cells. Cancer-based changes in those cells were confined to modification of cellular membrane and to appearance of changes in the cellular ultrastructures. In general, neoplasia was characterized by the occurrence in the haemolymph of large granular cells with hypertrophic and hyperchromatic nuclei, increased mitotic activity and changes in the cells ultrastructures. General pathological conditions identified as neoplastic and occurring in M. balthica have previously been described by Christensen et al. (1974), Farley (1976), Pekkarinen (1993) and Smolarz et al. (2003, 2005a and b).

In Macoma balthica from the Gulf of Gdansk, neoplasia was for the first time identified in 1995 (Thiriot-Quiévreux and Wołowicz 1996) and is regarded as a serious problem, probably linked to bad environmental conditions and the occurrence of pollutants (Thiriot-Quiévreux and Wołowicz 2001). Since then a number of studies have been performed in order to define the etiology and to show the characteristic of the cancer (Smolarz et al. 2003, Sokołowski et al. 2004, Smolarz et al. 2005a and b, Wołowicz et al. 2005).

Ultras tructural study of neoplas tic cells in Macoma balthica from the Gulf of Gdansk (Poland), Smolarz et al.email:smok@sat.ocean.univ.gda.pl 
This paper describes electron microscopy characteristics of neoplastic cells of M. balthica from the Gulf of Gdansk to assess the diagnosis of neoplasia. It describes the putative occurrence of myofibroblast-like cells and probable fibrosarcoma in the Baltic clam.

\section{Material and methods}

Fifty animals of $M$. balthica (shell length range from 10 to $20 \mathrm{~mm}$ ) were collected by dredging in the Gulf of Gdansk (Baltic Sea, Poland) in summer 2004.

For his to logical analyses, the body of each individual was removed from the shell and placed in the Davidson's fixative for $48 \mathrm{~h}$. In addition, small gill pieces, muscles and gonads (3-4 mm thick) were cut and fixed in Carlson's fixative. Samples were dehydrated through an ascending ethanol series, cleared in xylene and embedded in paraffin. Histological blocks were sectioned at $2 \mu \mathrm{m}$ thickness. Sections were stained (H\&E) and carefully checked for the presence of abnormalities related to neoplasia. Accurate staging of the disease progression was not performed.

After the light microscopy examination of histological sections, clams affected by neoplasia were selected and processed for transmission electron microscopy (TEM). For TEM analyses, 3 - $4 \mathrm{~mm}$ thick transverse sections of gonad, gills and foot muscle were placed in $3 \%$ gluteraldehyde in cacodylate buffer (1100 mOsm, $\mathrm{pH} 7.4$ ) for $2 \mathrm{~h}$ at $4{ }^{\circ} \mathrm{C}$, fixed in $1 \%$ osmium tetroxide in the same buffer for $1 \mathrm{~h}$, at $4{ }^{\circ} \mathrm{C}$ and rinsed twice in cacodylate buffer (1100 mOsm, pH 7.4) for $10 \mathrm{~min}$. Samples were then dehydrated through an ascending ethanol series, rinsed twice in propylene oxide and gradually infiltrated in propylene oxide/Epon resin (50:50) with in $20 \mathrm{~min}$. Samples were embedded in 100\% Epon resin and polymerised at $60{ }^{\circ} \mathrm{C}$ for $48 \mathrm{~h}$. Blocks were sectioned at 0.5 to $1 \mu \mathrm{m}$ thickness, stained with toluidine blue in $1 \%$ aqueous sodium borate solution at $100{ }^{\circ} \mathrm{C}$, rinsed with distilled water and checked with the light microscope. Based on the microscopic observations, selected blocks

Ultras tructural study of neoplas tic cells in Macoma balthica from the Gulf of Gdansk (Poland), Smolarz et al.email:smok@sat.ocean.univ.gda.pl 
were further processed and sectioned for electron microscopy examination. Ultra-thin sections were cut, collected on copper grids and double stained with uranyl acetate and lead citrate. Sections were analysed under a Jeol JEM 1200 EX transmission electron microscope at a voltage of $80 \mathrm{kV}$.

\section{Results}

Out of 50 animals 11 clams presented abnormal changes identified as neoplasia, giving an overall prevalence of $22 \%$. Based on histological analysis, clams with neoplasia were characterized by enlarged, undifferentiated cells presenting a high nucleus-to-cytoplasm ratio, a high mitotic index and cellular and nuclear polymorphism (Fig. 1a). Neoplasia was primarily observed in gills, connective tissue of gills and digestive gland (Fig. 1b). In the more advanced cases of cancer, abnormal cells were found in all organs throughout the body. Electron microscopy analyses were performed on six chosen clams that were severely affected by the cancer. Electron microscopy representation of neoplasia is shown in Fig. 2 to 4. Cells manifesting systemic neoplasia were found to exist in two types, abnormal roundshaped hypertrophic cells and irregular spindle-shaped cells. Abnormal round-shaped cells had irregular nuclei, dense cytoplasm, and a high nuclear-cytoplasmic ratio. These cells were seen in gills and other organs (Fig. 2a). Mitochondria were aggregated and enveloped by an undefined structure named here a pseudo-membrane (Fig. 2b and c). A high number of free ribosomes was also observed in the neoplastic cells.

Spindle-shaped cells occurred in animals suffering from advanced lesion of neoplasia. These lesional cells had eosinophilic cytoplasm and spindled nuclei with tapered ends. Nuclei of the spindle-shaped cells had a tendency to be orientated as in a palisade (Fig. 3). These cells had a finely granular or fibrous cytoplasm with elongate polymorphic, hyperchromatic, irregularly shaped nuclei and a high nucleus-to-cytoplasm ratio (Fig. 4). They were often primarily

Ultras tructural study of neoplas tic cells in Macoma balthica from the Gulf of Gdansk (Poland), Smolarz et al.email:smok@sat.ocean.univ.gda.pl 
observed in the connective tissue of gills or muscles, blood and lymphatic vessels. Meandering invaginations gave the nucleus envelope a lobulated appearance. This kind of cells also contained intracytoplasmic filaments. The gill epithelium was composed of thicker and tapered fibrocytes. In the very advanced cancer, elongated cells occurred in all tissues and organs. Pathological characteristics of both cancer forms include the proliferation of abnormal cells throughout the open circulatory system, metastasis to the adjacent organs, displacement, degeneration and necrosis of normal tissue (Fig. 1b and 5).

The results of the analyses can be summarized as follows. First, round-shaped cells were detected in all eleven abnormal clams. Secondly, five out of eleven clams diagnosed as neoplastic ( $45.5 \%$ of all abnormal cases) were characterized by the coexistence of abnormal cells of both types, namely round and spherical (Fig. 6). The entire lesions were typically very cellular.

\section{Discussion}

Several changes in cell ultrastructures confined to anatomic structure, shape and functions of neoplastic cells have been described in this paper. The paper by Farley (1976) involves the only previous description of neoplastic changes in the cell ultrastructures of Macoma balthica. In that paper the author describes nuclear hypertrophy, modifications of cellular membrane manifested by the lobulated appearance of the nucleus, high number of free ribosomes and high mitotic activity of cancer cells. Frequently observed nuclear hypertrophy comprise a characteristic feature of many cancer diseases and have been described by several authors (e.g. Christensen et al. 1974, Mix et al., 1979, Elston et al., 1992, Villalba et al., 2001, Smolarz et al. 2003). Moreover, the presence of atypical mitochondria, free ribosomes, nuclear and nucleolar hypertrophy and multiple nucleoli frequently noted in affected clams shows the adaptation of neoplastic cells to the increased mitotic activity. The occurrence of

Ultras tructural study of neoplas tic cells in Macoma balthica from the Gulf of Gdansk (Poland), Smolarz et al.email:smok@sat.ocean.univ.gda.pl 
swollen membrane folds in cellular matrix of gill cells observed in the cancer cells may reflect functional changes linked to increased pinocytotic activity or intercellular transport. Moreover, Farley (1976) also noted an increased number of glycogen granules, confirming the adaptation of cancer cells to higher mitotic activity. Furthermore, Rasmussen (1986) observed a high number of hypertrophic mitochondria and cellular matrix filled with small vesicles of smooth and rough endoplasmatic reticulum. Swollen intracristal spaces and increased density of mitochondrion matrix frequently noted in abnormal clams might be a sign of weakness of the cell and/or their mortality. For example, metallic pollutants in the sediments might cause ultrastructural changes in mitochondria, as was previously described by Squibb and Fowler (1981) and Aloj Totaro et al. (1986). The division of fibrilar and granular parts of the nucleus of neoplastic cells presented here may suggest an involvement of environmental genotoxins in the induction of neoplasia (Auffret and Poder 1986). This kind of division appears to be typical in the cells exposed to carcinogenic or antimetabolic substances. It can be hypothesized that genotoxins and other mutagenic substances occurring in the Gulf of Gdansk initiate the cancer progression directly in the cell ultrastructures. Since the first identification of neoplasia in M. balthica from the Gulf of Gdansk in 1995 (ThiriotQuiévreux and Wołowicz 1996), a number of studies have been performed in order to define the etiology and to give characteristics of the cancer (Thiriot-Quiévreux and Wołowicz 2001, Smolarz et al. 2003, Smolarz et al. 2005a). Recent data from the concurrent monitoring of the surface sediment's toxic influence to benthic organisms (ToxAlert test) suggests a direct relationship between the sediment toxicity and the prevalence of neoplasia (Wilcoxon test, $\mathrm{p}<0.02$ ), highlighting the impact of sediments on the tumour' etiology (Wołowicz et al. 2005, Smolarz et al. 2005 b).

In the present study, cells manifesting systemic neoplasia were found to exist in two types, abnormal round-shaped hypertrophic cells and irregular spindle-shaped cells. The observed 
spindle-shaped cells containing intracytoplasmic filaments were interpreted as probable myofibroblasts. The term "myofibroblast" defines cells that exhibit some of the ultrastructural and biochemical features of both smooth muscle cells and fibroblasts, including the presence of fibers and the expression of actin (Majno et al. 1971, Desmouliére 1995). It is a common knowledge that the myofibroblasts play an important role in healing processes and in fibrotic diseases in vertebrates (Nakatsuji et al. 1997, Schürch et al. 1998). Moreover, it has been suggested that myofibroblasts may constitute a unique expression of host response to neoplasia, as it was demonstrated for the Hodgkin's disease in humans (Seemayer et al. 1980, Batsakis et al. 1982). Myofibroblast-like cells were found only in the invasive and metastasising carcinomas. In the venerid clams Tapes decussatus and T. semidecussatus this type of cells was also observed in areas affected with the parasite Perkinsus atlanticus (Montes et al. 1997). Because of infiltration by granulocytes and demarcation by myofibroblast-like cells and extracellular matrix, Montes et al. (1997) interpreted these areas as a singular defensive response to infection with the parasites. Van der Knaap et al. (1993) reported that invertebrate hemocytes constitute a population with morphological and functional heterogeneity. Lebel et al. (1996), based on hemocyte morphological characteristics of the gastropod Haliotis tuberculata, distingu ished two categories of cells represented by the fibroblast-like cells and the epithelial-like cells. The fibroblast is a remarkable cell capable of a wide variety of phenotypic modulations in response to physiological conditions that include transformation into cells with contractive potential such as myofibroblast. Neoplasm composed of proliferating fibroblasts and myofibroblasts is also known as malignant fibrosarcoma and myofibrosarcoma (Jochum et al. 2004) and has been commonly described in vertebrates. In this paper, all cases with fibrosis showed the proliferation of myofibroblast-like cells in the digestive gland, gills and adjacent mantle tissue. Proliferation of fusiform cells may be interpreted as probable fibrosarcoma. This kind

Ultras tructural study of neoplas tic cells in Macoma balthica from the Gulf of Gdansk (Poland), Smolarz et al.email:smok@sat.ocean.univ.gda.pl 
of cancer represents a type of neoplasia that arises from fibroblast-like cells or mesenchymal cells capable of producing fibers. The cancer is also characterized by the occurrence of fibers, hyperchromatic and pleomorphic nuclei (Batsakis et al., 1982). The diagnosis was partly confirmed by the existence of atypical spindle cells orientated as in a palisade with slender nuclei and scant cytoplasm. The presence of focal anaplasia and increased mitotic activity was paramount, and aggressive clinical behaviour (increased mitotic activity, metastases) was taken into account when making a histopathological diagnosis. Nevertheless, poorly differentiated fibrosarcoma described here demonstrated smaller, more aggressive and more primitive cells than the well-differentiated lesion. Fibrosarcoma has already been observed in the gonadal stroma of Mytilus sp. and Crassostrea virginica (Peters et al. 1994).

Pathological characteristics of both cancer forms reported here were similar to those reported for neoplastic conditions in general and include the proliferation of abnormal cells throughout the open circulatory system to the adjacent organs, metastases, displacement, degeneration and necrosis of normal tissue. On that basis it is hypothesised that round and spindle-shaped cells described here appear to represent cytomorphological differences in cell types of the same proliferative disorder, as is neoplasia. Both forms were also characterized by the occurrence of highly anaplastic large granular cells with pleomorphic nuclei, atypical mitochondria, high mitotic activity and a high nuclei-cytop lasm ratio. All these characteristics represent typical features of rapidly proliferating neoplasm (Christensen et al. 1974, Elston et al. 1992, Villalba et al. 2001). Farley (1976) merely describes the occurrence of round-shaped abnormal cells, while the occurrence of spindle-shaped cells reported in this study has not been previously noted. Moreover, Thiriot-Quiévreux and Wołowicz (2001), studying neoplastic disease in M. balthica from the Gulf of Gdańsk, described karyological damages manifested by chromosomal alternations and inferred the coexistence of another specific but undefined type of neoplasia.

Ultras tructural study of neoplas tic cells in Macoma balthica from the Gulf of Gdansk (Poland), Smolarz et al.email:smok@sat.ocean.univ.gda.pl 
The fact that phenotypic differences occur in the two cell types discussed above suggests two things: First that the described anomalies refer to disseminated neoplasia because roundshaped cells typical for this cancer type appeared in all affected clams. Additionally, the appearance of spindle-shaped cells was only detected in a few affected bivalves and only together with round-shaped cells - these two abnormal cell types probably represent different types of co-occurring neoplasms in the examined clams, namely disseminated neoplasia and probable fibrosarcoma.

Fibroblastic neoplasms usually have a variable immunoreactivity, and the more pleomorphic the tumour, the more difficult it is to determine the tissue of its origin (Erlandson and Woodruff 1998). Thus it must be emphasized that the presence of spindle-shaped cells only implies the cytological origin of the cancer and by that suggest the presence of fibrosarcoma.

\section{Acknowledgement}

Electron microscopy analyses were supported by funds from the Polish-French cooperation programme. Our sincere gratitude is extended to A. Mitwer (Northstream, Sweden) for correcting the English text. Dr. A. Sokolowski (University of Gdansk, Poland) is sincerely acknowledged for helpful comments while writing the manuscript and for correcting the English text.

Dr. P. Goulletquer is acknowledged for allowing the work at the IFREMER laboratory in La Tremblade. 


\section{References}

Aloj Totaro, E., Pisanti, F.A., Glees, P., Continillo, A., 1986. The effect of copper pollution on mitochondrial degeneration. Mar. Environ. Res. 18:245-253.

Auffret, M., Poder, M., 1986. Sarcomatous lesion in the cockle Cerastoderma edule. II. Electron microscopical study. Aquaculture 58:9-15.

Barber, B.J., 2004. Neoplastic diseases of commercially important marine bivalves. Aquat. Living Resour. 17:449-466.

Batsakis, J.G., Rice, D.H., Howard, D.R., 1982. The pathology of head and neck tumors: spindle cell lesions (sarcomatoid carcinomas, nodular fascitis, and fibrosarcoma) of the aerodigestive tracts: part 14. Head Neck Surg. 4:499-513.

Christensen, D.J., Farley C.A., Kern F.G., 1974. Epizootic neoplasms in the clam Macoma balthica (L.) from Chesapeake Bay. J. Natl. Cancer Inst. 52:1739-1749

Desmouliére, A., 1995. Factors influencing myofibroblast differentiation during wound healing and fibrosis. Cell Biol. Intern. 19:471-476.

Elston, R.A., Moore, J.D., Brooks, K., 1992. Disseminated neoplasia of bivalve molluscs, Rev. Aquat. Sci. 6:405-466. 
Erlandson, R.E., Woodruff, J.M., 1998. Role of electron microscopy in the evaluation of soft tissue neoplasms, with emphasis on spindle cell pleomorphic tumors. Hum. Pathol. 29:13721381.

Farley, C.A., 1969. Probable neoplastic disease of the hematopoietic system in oysters, Crassostrea virginica and C. gigas. Natl. Cancer Inst. Monogr. 31:541-555.

Farley, C.A., 1976, Ultrastructural observations on epizootic neoplasia and lytic virus infection in bivalve molluscs. Progr. Experim. Tumor Res. 20:283-294.

Jochum, W., Hänggi, D., Bruder, E., Jeck, T., Novotny, H., Probst, A., Tolnay, M., 2004. Inflammatory myofibroblastic tumour of the sella turcica. Neuropath. Applied Neurobiol. 30:692-695.

Knaap van der, W.P.W., Adema, C.M., Sminia, T., 1993. Invertebrate blood cells: morphological and functional aspects of the haemocytes in the pond snail Lymnaea stagnalis. Comp. Haematol. Int. 3:20-26.

Lebel, J.M., Giard, W., Favrel, P., Boucard-Camou, E., 1996. Effects of different growth factors on primary cultures of hemocytes from the gastropod mollusc, Haliotis tuberculata. Cell Biol. 86:67-72.

Majno, G., Gabbiani, G., Hirschel, B. J., Ryan, G. B., Statkov, P. R., 1971. Contraction of granulation tissue in vitro: similarity to smooth muscle. Sci. 173:548.

Ultras tructural study of neoplastic cells in Macoma balthica from the Gulf of Gdansk (Poland), Smolarz et al.email:smok@sat.ocean.univ.gda.pl 
Mix, M.C., 1983. Haemic neoplasms of bay mussels, Mytilus edulis, from Oregon : Occurrence, prevalence, seasonality and histopathological progression. J. Fish. Dis. 6:239248.

Mix, M.C., Hawkes, J.W., Sparks, A.K., 1979. Observations of the ultrastructure of large cells associated with putative neoplastic disorders in mussels, Mytilus edulis, from Yaquina Bay, Oregon. J. Invertebr. Pathol. 34:41-56.

Montes, J.F., Del-Rio, J.A., Durfort, M., Garcia-Valero, J., 1997. The protozoan parasite Perkinsus atlanticus elicits a unique defensive response in the clam Tapes semidecussatus. Parasitology 114:339-349.

Nakatsui, S., Yamate, J., Kuwamura, M., Kotani, T., Sakuma, S., 1997. In vivo responses of macrophages and myofibroblasts in the healing following isoproterenol-induced myocardial injury in rats. Virchow Arch. 430:63-69.

Pekkarinen M., 1993, Neoplastic diseases in the Baltic Macoma balthica (Bivalvia) off the Finnish Coast. J. Invertebr. Pathol. 61:138-146

Peters, E.C., Yevich, J.C., Harshbarger, J.C., Zaroogian, G.E., 1994. Comparative histopathology of gonadal neoplasms in marine bivalve molluscs. Dis. Aquat. Org. 20:59-76.

Rasmussen, L., 1986. Cellular reactions in mollusks with special reference to chemical carcinogens and tumors in natural populations of bivalve mollusks. In: Proceedings, Fourth Int. Colloq. Invertebr. Pathol., NL. pp 441-443.

Ultras tructural study of neoplas tic cells in Macoma balthica from the Gulf of Gdansk (Poland), Smolarz et al. email:smok@sat.ocean.univ.gda.p1 
Schürch, W., Seemayer, T., Gabbiani, G., 1998. The myofibroblast. A quarter century after its discovery. Am. J. Surg. Pathol. 22:141-147.

Seemayer, T.A., Lagacé, R., Schürch, W., Thelmo, W.L., 1980. The myofibroblast: biologic, pathologic, and theoretical considerations. Pathol. Annu. 15:443-470.

Smolarz, K., Wołowicz, M., Thiriot-Quiévreux, C., 2003. Argyrophilic nucleolar organizer regions (AgNORs) in interphases and metaphases of normal and neoplastic gill cells of Macoma balthica (Bivalvia: Tellinidae) from the Gulf of Gdańsk, Baltic Sea. Dis. Aquat. Org. $56: 269-274$.

Smolarz, K., Thiriot-Quiévreux, C., Wołowicz M., 2005 (b). Recent trends in the prevalence of neoplasia in the Baltic clam Macoma balthica (L.) from the Gulf of Gdańsk (Baltic Sea). Oceanologia 47:61-74.

Smolarz, K., Renault, T., Soletchnik, P., Wołowicz M., 2005 (a). Neoplasia detection in Macoma balthica L. (Bivalvia) from the Gulf of Gdańsk (Baltic Sea, Poland) - Comparison of flow cytometry, histology and chromosome analysis. Dis. Aquat. Org., 66:41-46.

Sokołowski, A., Wołowicz, M., Hummel, H., Smolarz, K., Fichet, D., Radenac, G., ThiriotQuievréux, C., Namieśnik, J., 2004. Abnormal features of Macoma balthica (Bivalvia) in the Baltic Sea: alerting symptom of environmental changes?. Mar. Poll. Bull. 49:17-22.

Squibb, S., Fowler, B.A., 1981. Relationship between metal toxicity to subcellular systems and the carcinogenic response. Environ. Health Perspect. 40:181-188.

Ultras tructural study of neoplastic cells in Macoma balthica from the Gulf of Gdansk (Poland), Smolarz et al.email:smok@sat.ocean.univ.gda.pl 
Thiriot-Quiévreux, C., Wołowicz, M., 1996. Etude caryologique d'une néoplasie branchiale chez Macoma balthica (Mollusca, Bivalvia). C. R. Acad. Sci. 319:887-892.

Thiriot-Quiévreux, C., Wołowicz, M., 2001. Chromosomal study of spatial variation of the prevalence of a gill neoplasia in Macoma balthica from the Gulf of Gdańsk (Baltic Sea). Ophelia 54:75-81.

Villalba, A., Carballal, M.J., Lopez, C., 2001. Disseminated neoplasia and large foci indicating heavy haemocytic infiltration in cockles Cerastoderma edule from Galicia (NW Spain). Dis. Aquat. Org. 46:213-216.

Wołowicz, M., Smolarz, K., Sokołowski, A., 2005, Neoplasia in estuarine bivalves: effect of feeding behaviour and pollution in the Gulf of Gdańsk (Baltic Sea, Poland). NATO Science Series IV: Earth and Environmental Sciences, Kluwer Academic Publishers B.V., NATO Special Edition. 165-182.

Ultras tructural study of neoplas tic cells in Macoma balthica from the Gulf of Gdansk (Poland), Smolarz et al.email:smok@sat.ocean.univ.gda.pl 
Fig. 1a and b. Histological section through gills of M. balthica with neoplasia showing: (a) large neoplastic cells with hypertrophic nuclei, note round shaped cells with multiple nuclei (arrow), H\&E staining, scale bar $10 \mu \mathrm{m}$; (b) section showing severely damaged gills and proliferation of abnormal round-shaped cells, H\&E staining, scale $50 \mu \mathrm{m}$.

Fig. 2. Transmission electron micrographs (TEM) of neoplastic cells of M. balthica, scale 500 nm (a), (b) neoplastic cell with irregular nuclei, the high nuclear-cytoplasmic ratio and enveloped mitochondria (arrows), scale $1 \mu \mathrm{m}$, and (c) enlargement of figure (b) showing aggregated mitochondrion with swollen intracristal spaces and dense matrix, scale $1 \mu \mathrm{m}$.

Fig. 3. Neoplastic cells with irregular nuclei that tend to be orientated as in a palisade, Note enveloped mitochondria (arrows), V- vacuole, scale $1 \mu \mathrm{m}$. (TEM).

Fig. 4. A spindle-shaped cell (myofibroblast) with meandering inviginations of the nucleus envelope giving the nucleus the lobulated appearance. Note: the cell contains some intracytoplasmic filaments, scale $1 \mu \mathrm{m}$. G- glycogen deposits, Ag- Golgi complex, Re- rough endoplasmic reticulum, F- intracytoplasmic filaments (TEM).

Fig. 5. Fibrosis interpreted as probable fibrosarcoma, section through the foot of M. balthica, abnormal cells infiltrating free space between muscle fibers (right) and columnar epithelium (left), H\&E, scale $50 \mu \mathrm{m}$.

Fig. 6. Two apparently different forms of cancer coexisting in gills of the clam diagnosed as neoplastic, round shaped cells (arrow), spindle-cells (block arrow), H\&E staining, scale 10 $\mu \mathrm{m}$.

Ultras tructural study of neoplastic cells in Macoma balthica from the Gulf of Gdansk (Poland), Smolarz et al.email:smok@sat.ocean.univ.gda.pl 

Figure $1 \mathrm{a}$
Click here to download high resolution image

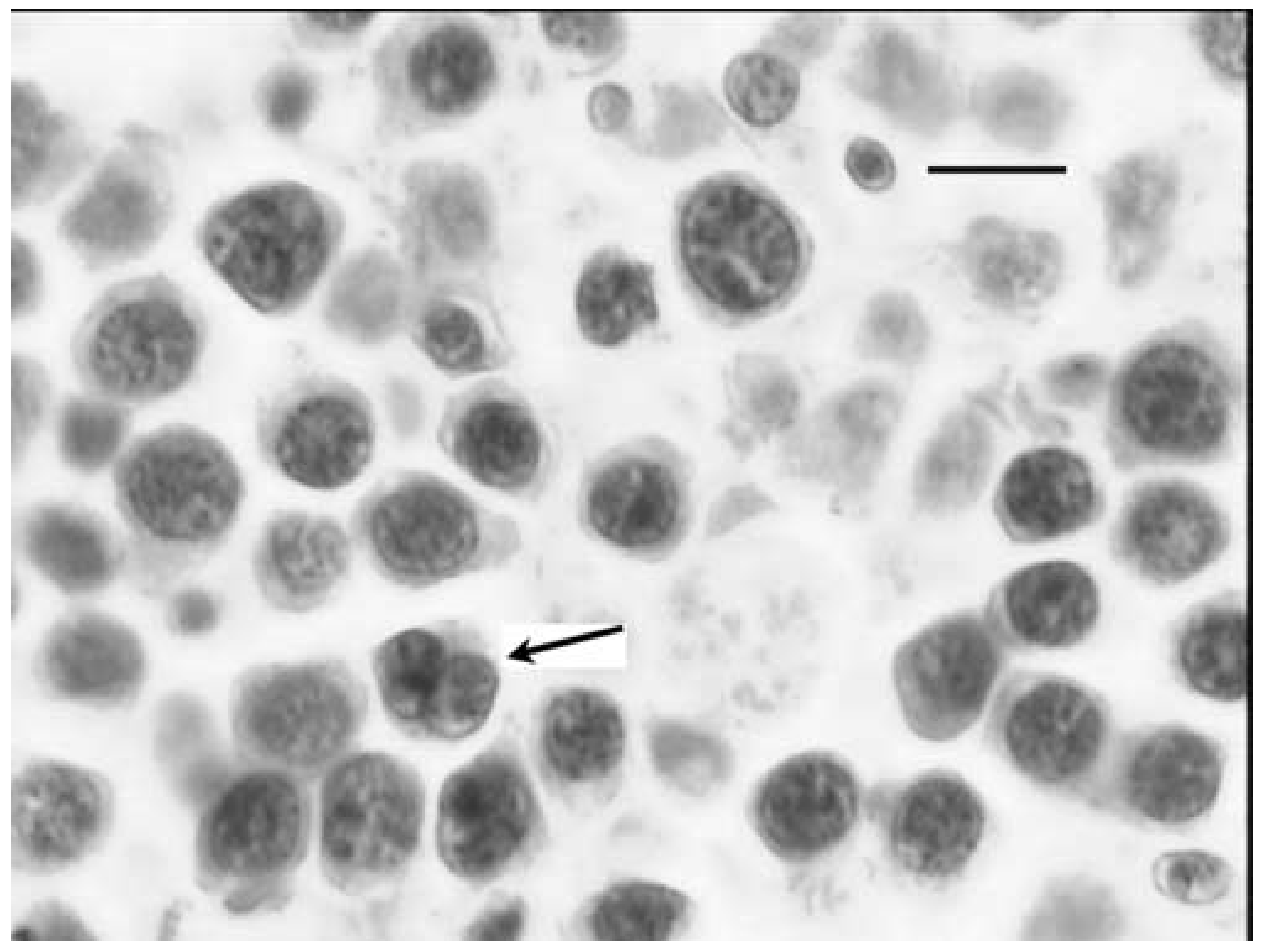


Click here to download high resolution image

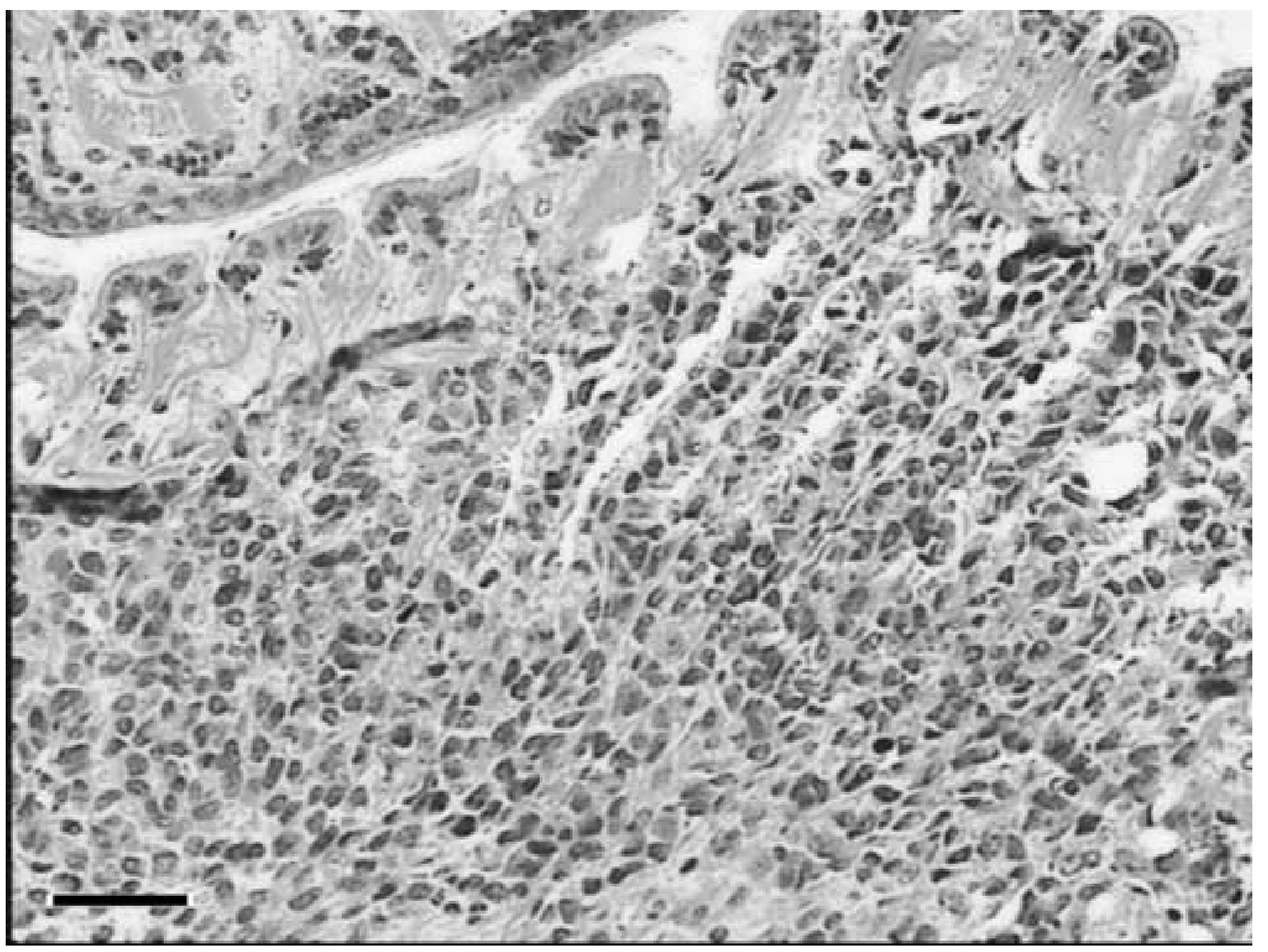


Click here to download high resolution image

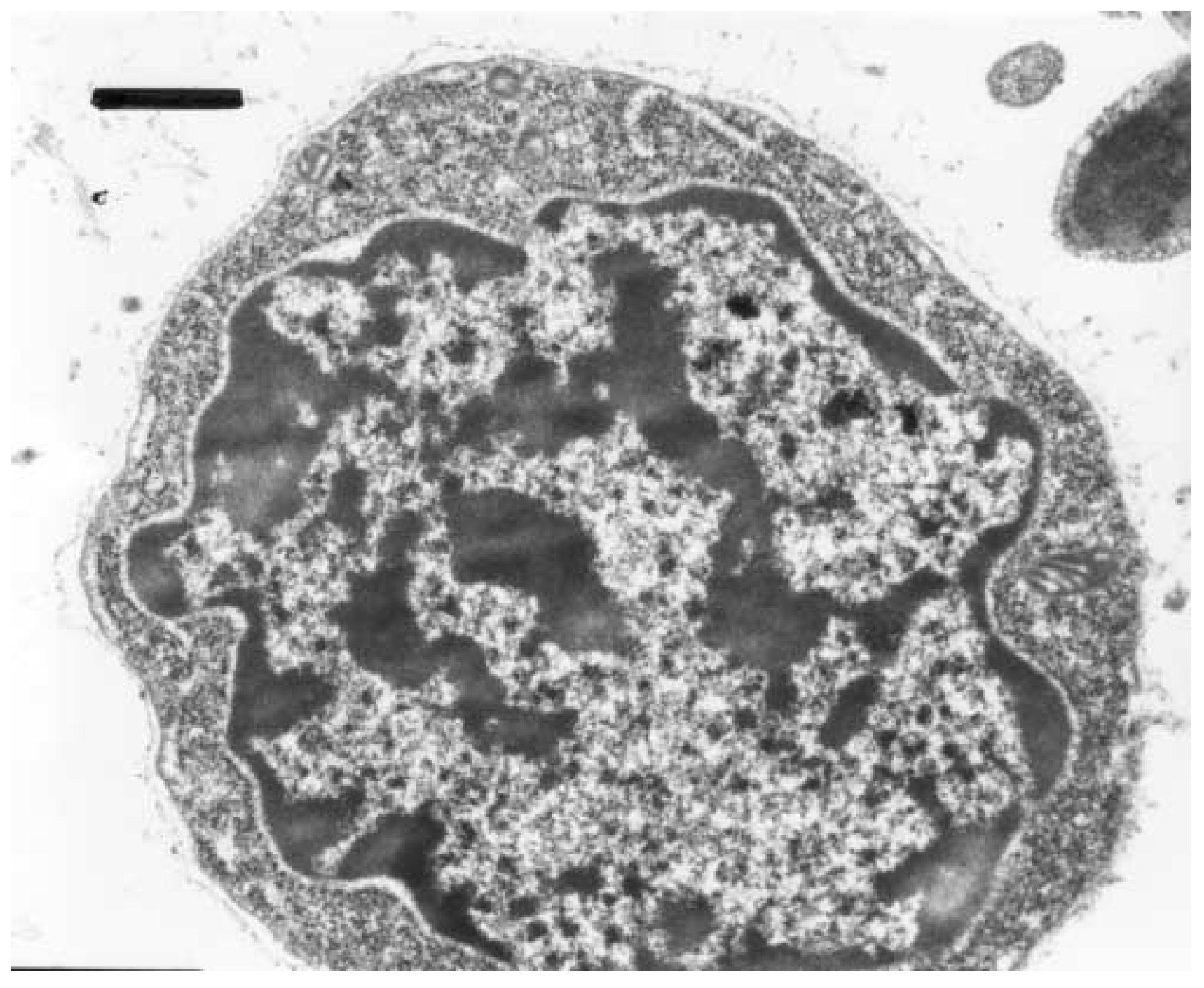




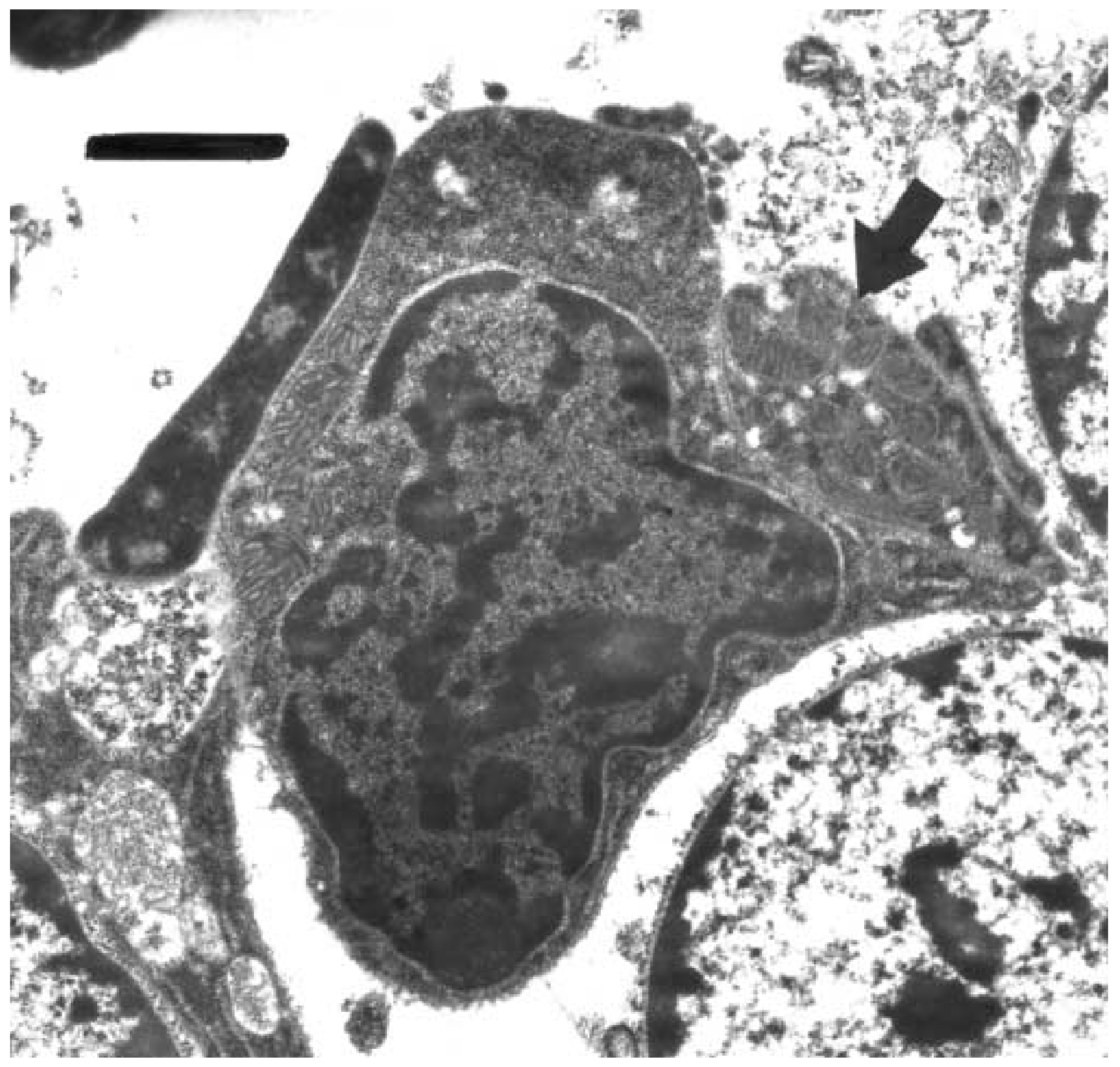


Figure $2 \mathrm{c}$
Click here to download high resolution image

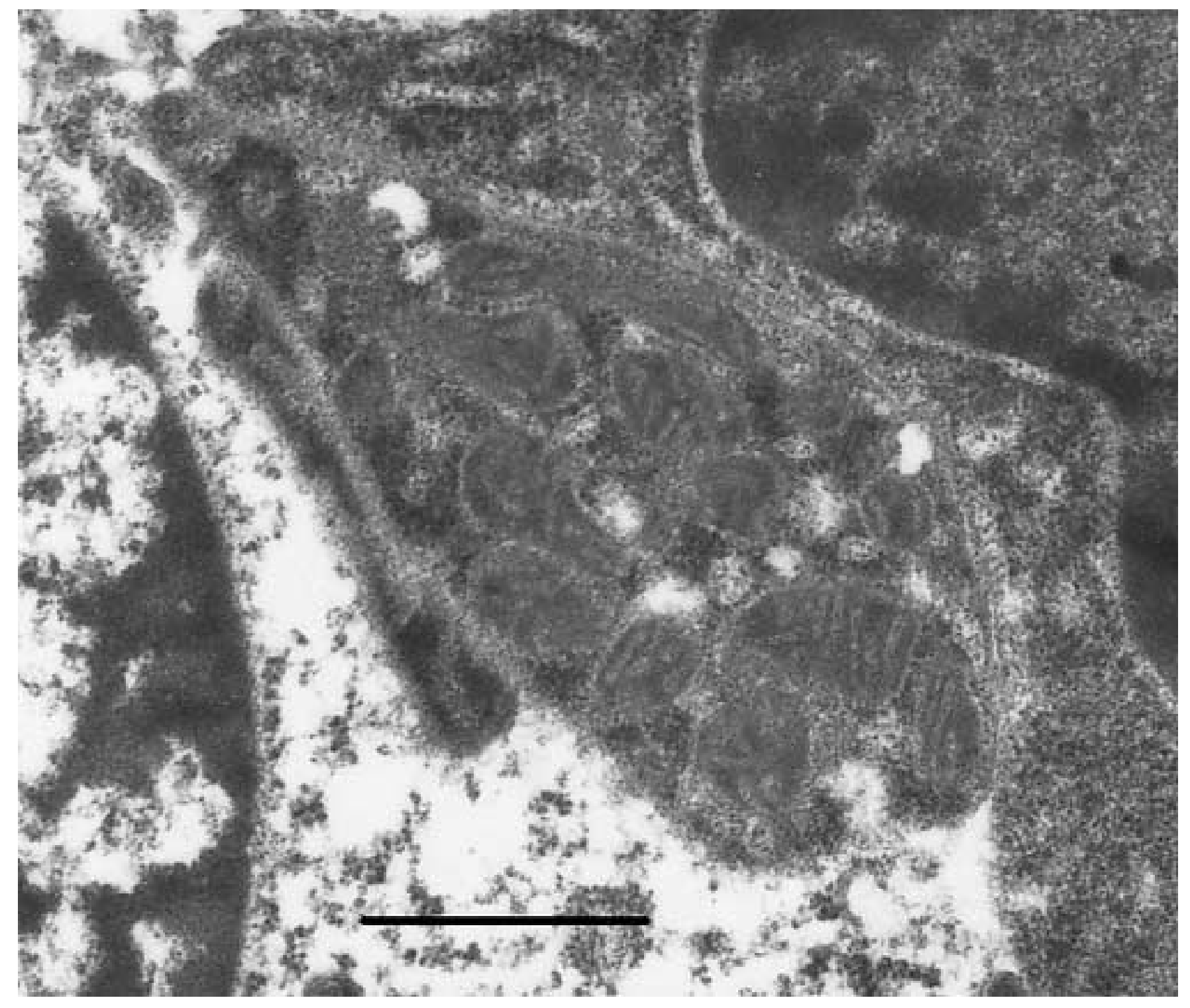


Figure 3
Click here to download high resolution image

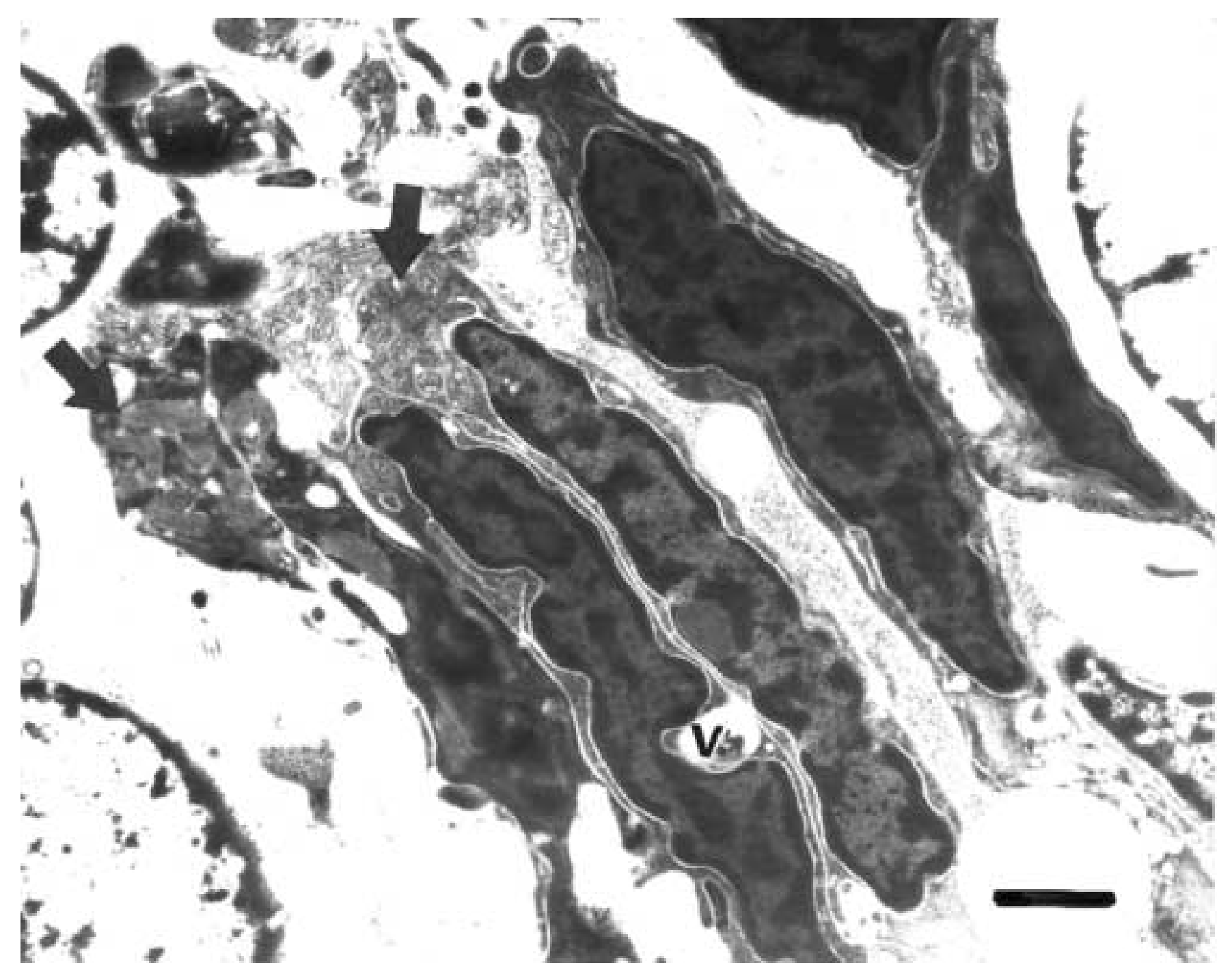


Figure 4

Click here to download high resolution image

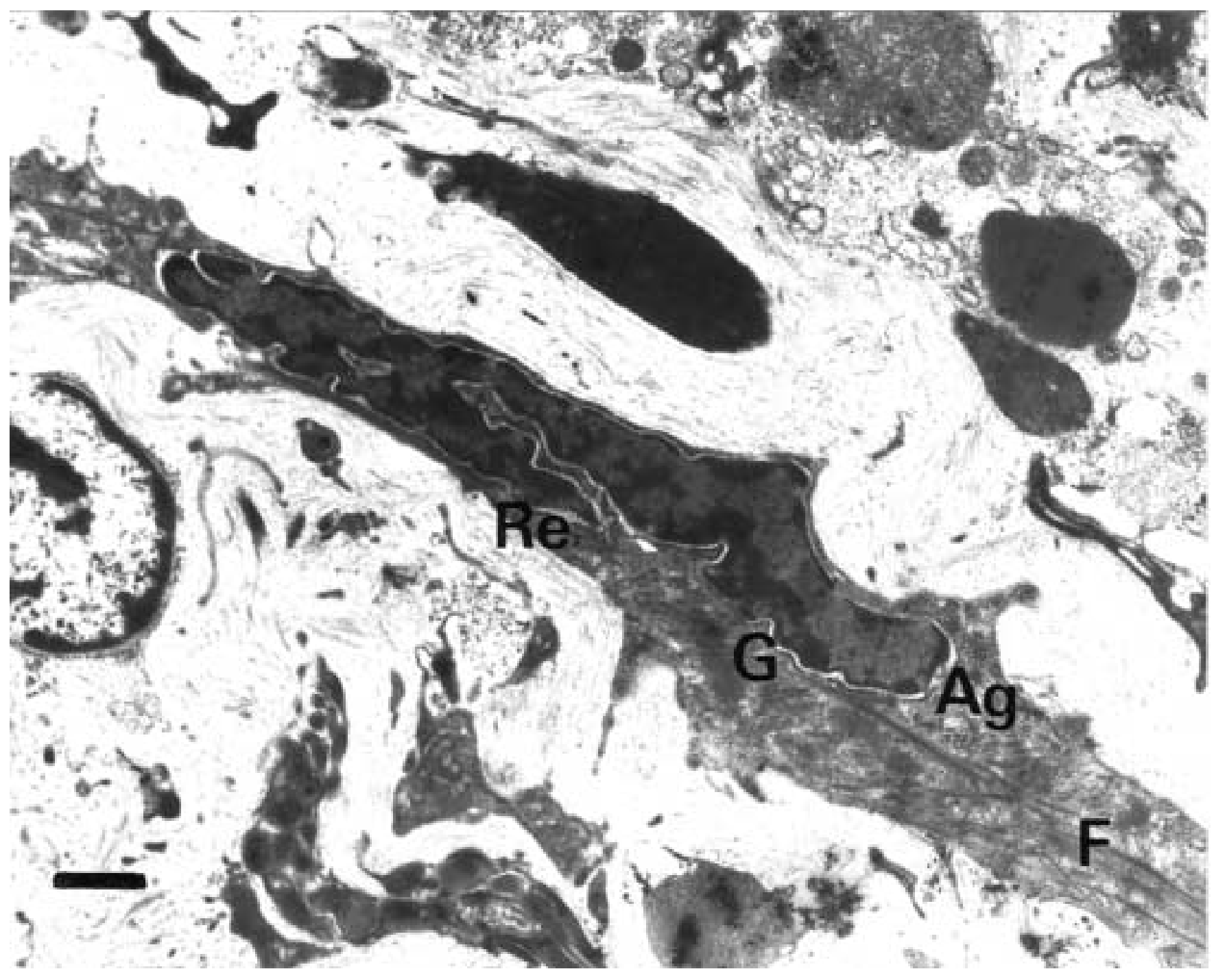


Click here to download high resolution image

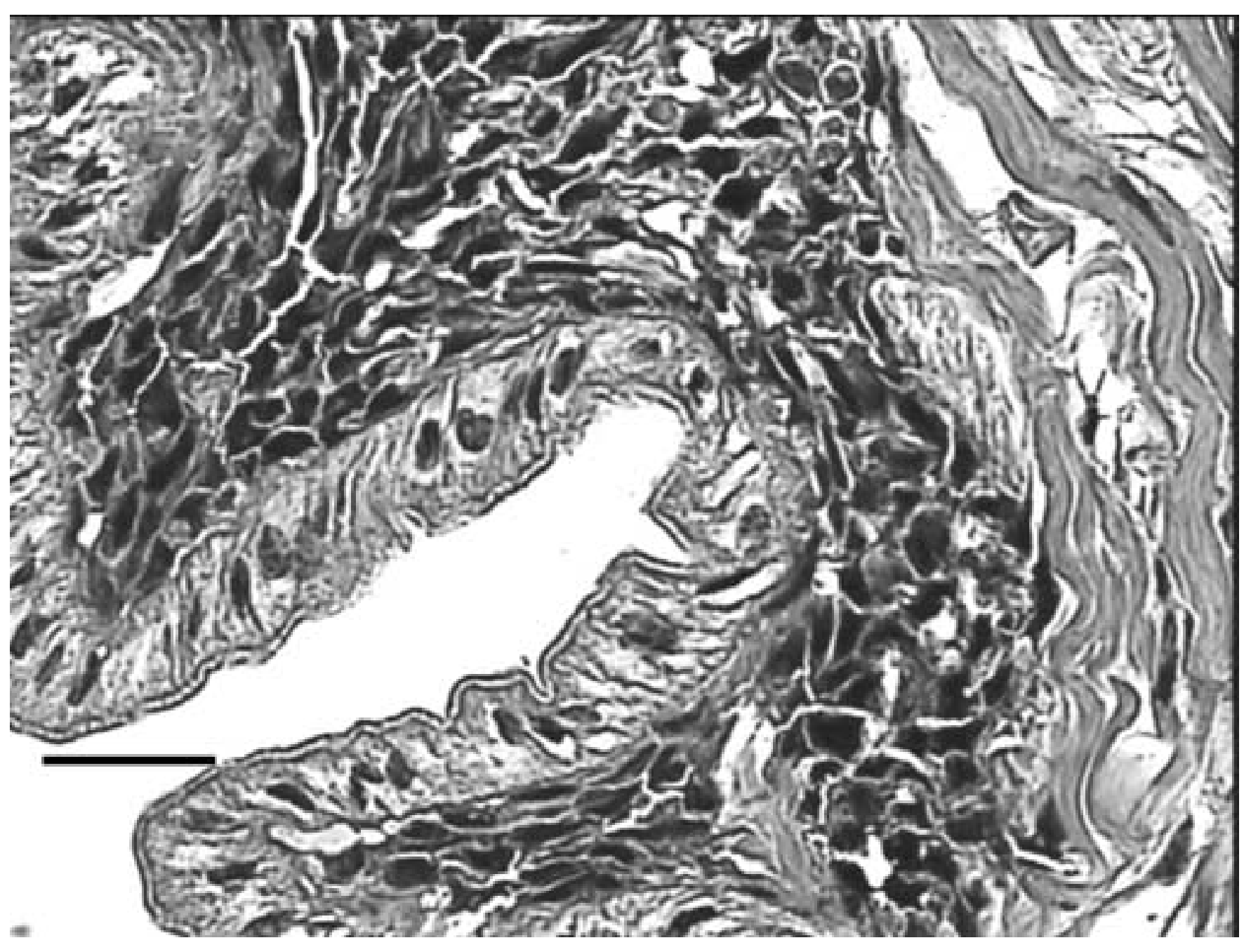

Figure 5

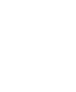

(n)

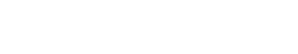


Click here to download high resolution image

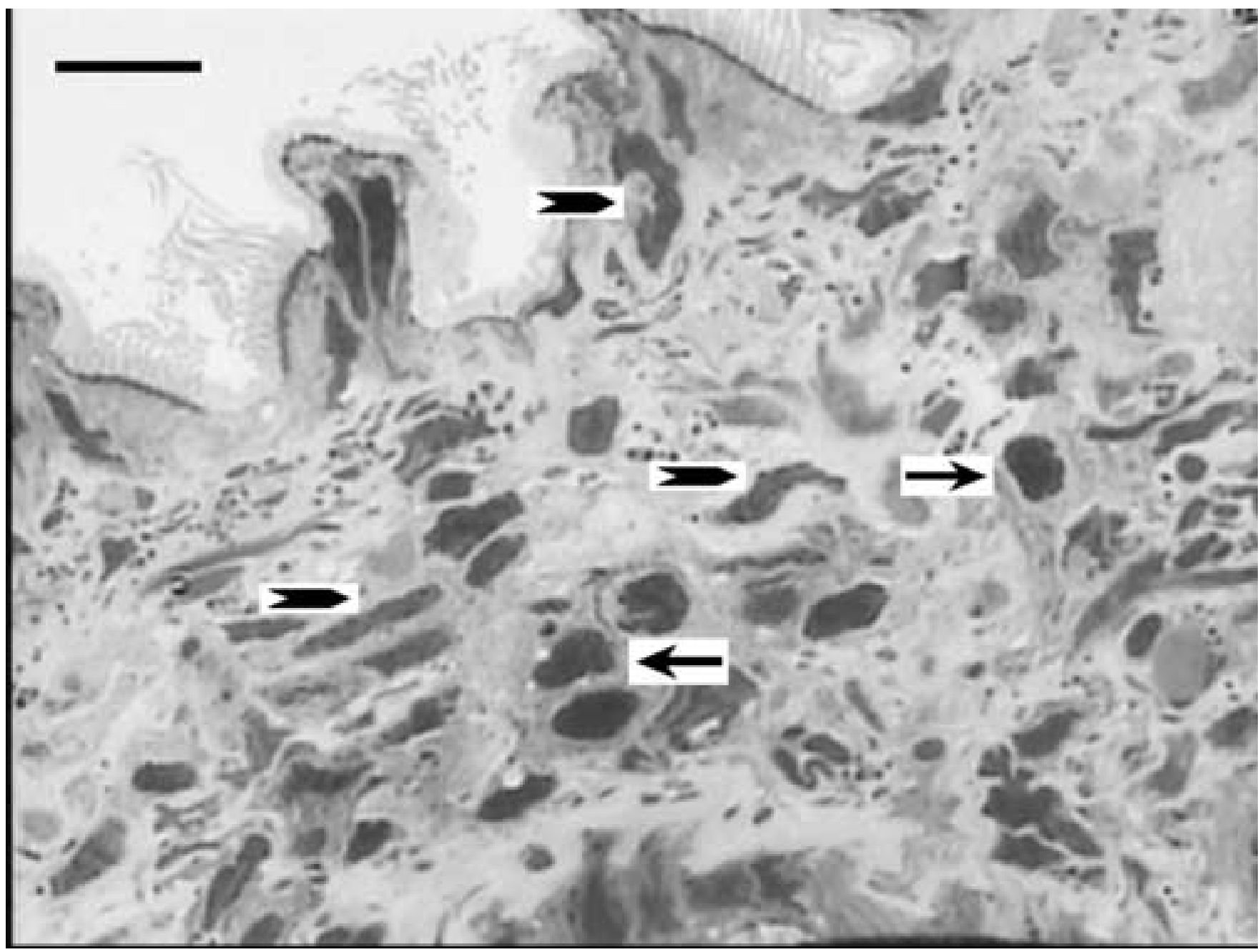

